\title{
Two new Cymatopleura taxa (Bacillariophyta) from Xinjiang, China with slightly twisted frustules
}

\author{
Qingmin You ${ }^{1,2}$, J. Patrick Kociolek ${ }^{2,3,4}$, Meijia CAI ${ }^{1}$, Pan Yu ${ }^{1} \&$ Quanxi WAnG ${ }^{1 *}$
}

1 College of Life and Environmental Sciences, Shanghai Normal University, Shanghai, China

2 Museum of Natural History, University of Colorado, Boulder, CO, USA

3 Department of Ecology and Evolutionary Biology, University of Colorado, Boulder, CO,USA

4 University of Michigan Biological Station, Pellston, MI, USA

\begin{abstract}
Two new species of the diatom genus Cymatopleura, Cymatopleura aquastudia and Cymatopleura xinjiangiana, that have torsion about the apical axis of the valves, are reported from Xinjiang Region, China, using light and scanning electron microscopy. The valves of Cymatopleura aquastudia sp. nov. exhibit torsion about the apical axis, are heteropolar, and are slightly constricted at the margin in the middle of the valves. These characters differentiate it from morphologically similar taxa in the genus, e.g. C. solea (BrÉBISSON) W. SMith and C. spiralis Behning in RauschenBach et Behning. The valves of Cymatopleura xinjiangiana sp. nov. also exhibit torsion about the apical axis, but are small and have curved ridges at both ends and rounded apices that are protracted at the wider ends. These features distinguish $C$. xinjiangiana from $C$. cochlea Brun and $C$. elliptica $\mathrm{f}$. spiralis BOYER. These two new taxa help to demonstrate the unique nature of the freshwater diatom flora from Xinjiang Region, China.
\end{abstract}

Key words: Bacillariophyta, China, Cymatopleura, new species, Xinjiang

\section{INTRODUCTION}

Cymatopleura W. Sмiтн (1851) frustules are generally large in size (SPAULDING \& EDLUND 2008) and more abundant in high-conductivity (alkaline) waters (Round et al. 1990). There are over 150 described taxa (Fourtanier \& Kociolek 2011), most of them were described before the middle of the last century. A few new species have been described recently, for example, from the Balkan Peninsula (Levkov et al. 2007), western North America (BAHLS 2013), and East Africa (CoCQUYT \& JAHN 2014). Due to the large size of their cells, Cymatopleura taxa have been easy to isolate and they are reported to be relatively easy to culture, making them useful for the study of ontogeny, meiosis, and auxospore formation (e.g. Pfitzer 1871; Karsten 1900, 1928; Thaler 1972; Mann 1987; Chang \& STEINBERg 1988).

As in the closely related genus Surirella TURPIN (RuCK \& KocioleK 2004; RuCK \& THeriot 2011), some species of Cymatopleura have been described to have a slight degree of torsion about the apical axis. Examples in Cymatopleura include $C$. cochlea Brun (1891), C. spiralis Behning (in Rauschenbach \& Behning 1912) and C. elliptica f. spiralis Boyer
(1916). And like many other areas (e.g. Ross 1983; CocQuYT \& JAHN 2005, 2007), in the Xinjiang Uygur Autonomous Region (shorter name: Xinjiang Region) of China, the number of Cymatopleura taxa reported are fewer than those of the genus Surirella TuRPIN (You 2009). You (2009) reported 25 species and 3 varieties of Surirella species and 3 species and 5 varieties of Cymatopleura species from this region.

We have begun to review the species occur-ring in Xinjiang Region, and many new species have already been described from this little-explored area in the northwest of China (Kociolek et al. 2015; You et al. 2008, 2009, 2013, 2015a, b). The purpose of the present study is to re-examine the Cymatopleura taxa from Xinjiang Region based on observations from light and scanning electron microscopy, and to describe two new species of the genus (C. aquastudia and C. xinjiangiana) that are twisted about the apical axis.

\section{Material and Methods}

Diatom samples were collected in various habitats from the Xinjiang Region in July 2001 and July 2007 (Table 1). In these samples, the new Cymatopleura species described here 
Table 1. Locality data and habitat for samples studied.

\begin{tabular}{|c|c|c|c|c|c|c|}
\hline No. & Locations & Habibat & $\begin{array}{c}\text { Water } \\
\text { Tempera- } \\
\text { ture }\left({ }^{\circ} \mathbf{C}\right)\end{array}$ & pH & $\begin{array}{l}\text { Collecting } \\
\text { Data }\end{array}$ & Collectors \\
\hline XJ010105 & Bachu & $\begin{array}{l}\text { Temporary water on the road- } \\
\text { side }\end{array}$ & 18 & - & 7.8. 2001 & $\begin{array}{l}\text { WANG Q.X,\& LI } \\
\text { H.L. }\end{array}$ \\
\hline XJ010112 & Akesu & Temporary water near the river & 13 & - & 7.25 .2001 & $\begin{array}{l}\text { WANG Q.X,\& Li } \\
\text { H.L. }\end{array}$ \\
\hline XJ010117 & Akesu & Little ditch & 14 & - & 7.25 .2001 & $\begin{array}{l}\text { WANG Q.X,\& LI } \\
\text { H.L. }\end{array}$ \\
\hline XJ010128 & Bohu & $\begin{array}{c}\text { Attached aquatic plants on the } \\
\text { lakeside }\end{array}$ & 15 & 8.5 & 7.25 .2001 & $\begin{array}{l}\text { WANG Q.X,\& LI } \\
\text { H.L. }\end{array}$ \\
\hline XJ010183 & Chabuchaer & $\begin{array}{l}\text { Temporary water on the road- } \\
\text { side, with Chara }\end{array}$ & 20 & 8.2 & 8.8.2001 & $\begin{array}{l}\text { WANG Q.X,\& LI } \\
\text { H.L. }\end{array}$ \\
\hline XJ010192 & Chabuchaer & $\begin{array}{l}\text { Temporary water on the road- } \\
\text { side, with Chara }\end{array}$ & 20 & 8.2 & 8.8.2001 & $\begin{array}{l}\text { WANG Q.X,\& LI } \\
\text { H.L. }\end{array}$ \\
\hline XJ071055 & Yecheng & $\begin{array}{l}\text { Little ditch, clean, with aquatic } \\
\text { plants }\end{array}$ & 24 & 8.5 & 7.17.2007 & $\begin{array}{l}\text { WANG Q.X,\& } \\
\text { YOU Q.M. }\end{array}$ \\
\hline
\end{tabular}

were found in both northern and southern Xinjiang; the specific localities are shown in Fig. 1. Samples were field-fixed in $4 \%$ formaldehyde, water temperature and $\mathrm{pH}$ were measured with a HANNA HI 98128 (HANNA instruments, Ann Arbor, MI) $\mathrm{pH}$ meter on site. In the laboratory, samples were treated with concentrated nitric acid using the Microwave Accelerated Reaction System (Model MARS, CEM Corporation, Charlotte, USA) (PARR et al. 2004) and a pre-programmed digestion scheme (temperature: $180{ }^{\circ} \mathrm{C}$, ramping up to the desired temperature in $15 \mathrm{~min}$, then maintain that temperature for $15 \mathrm{~min}$ ) (You et al. 2015a). After digestion, samples were alternatively centrifuged for 5 minutes at 3500 rpm (TDZ5-WS, Luyi Corporation, Shanghai, China), washed with distilled water and decanted, ca. five times, until the $\mathrm{pH}$ of the sample was approximately neutral. The cleaned material was kept in $95 \%$ ethanol.

Using cleaned material, permanent slides were made by mounting in Naphrax for light microscope (LM) observations. For scanning electron microscope (SEM) observations, cleaned material was air-dried onto coverslips and mounted onto $\mathrm{Cu}$ stubs. LM observations were made with an Olympus BX-51 microscope (Olympus America Inc., Center Valley, Pennsylvania, USA) fitted with DIC optics (100× objective, numerical aperture 1.4). Light micrographs were taken with an Olympus DP-71 digital camera. SEM examination was conducted using a JEOL JSM-6380LV (15 kV). Diatom images were compiled with Photoshop CS3.

Morphometry statistics for Cymatopleura aquastudia sp. nov. and C. xinjiangiana sp. nov. are provided. We measured a total of 30 valves for each species with respect to length, breadth, and ratio of length / breadth, and calculated the mean and standard deviation for these variables (Table 3 ). The measurements of length and width were made from LM and SEM images, terminology for the morphological description follows CocQuYT \& J $\mathrm{J}_{\mathrm{AHN}}(2005,2007,2014)$, Round et al. (1990) and Ruck \& Kociolek (2004).

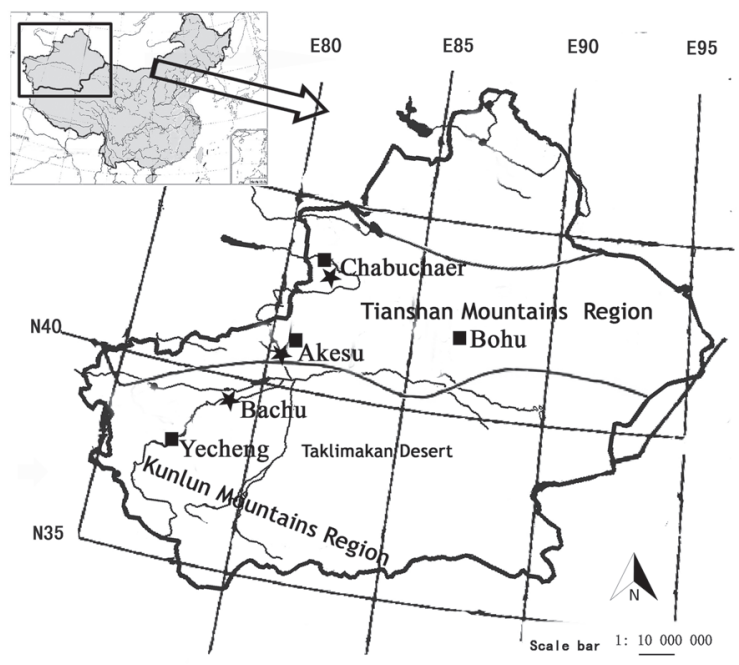

Fig. 1. Distribution of two new species in Xinjiang. "口"means $C y$ matopleura aquastudia, “ $\star$ " means Cymatopleura xinjiangiana.

\section{Results}

\section{Formal descriptions of new species}

Cymatopleura aquastudia Kociolek et You sp. nov. (Figs 2-17)

\section{Description}

Light microscopy (Figs 2-7): Frustules with a slight degree of torsion about the apical axis. Valves panduriform and slightly asymmetrical to the transapical axis, broadly rounded and wider at the head pole, slightly protracted and narrower at the foot pole, with constrict- 

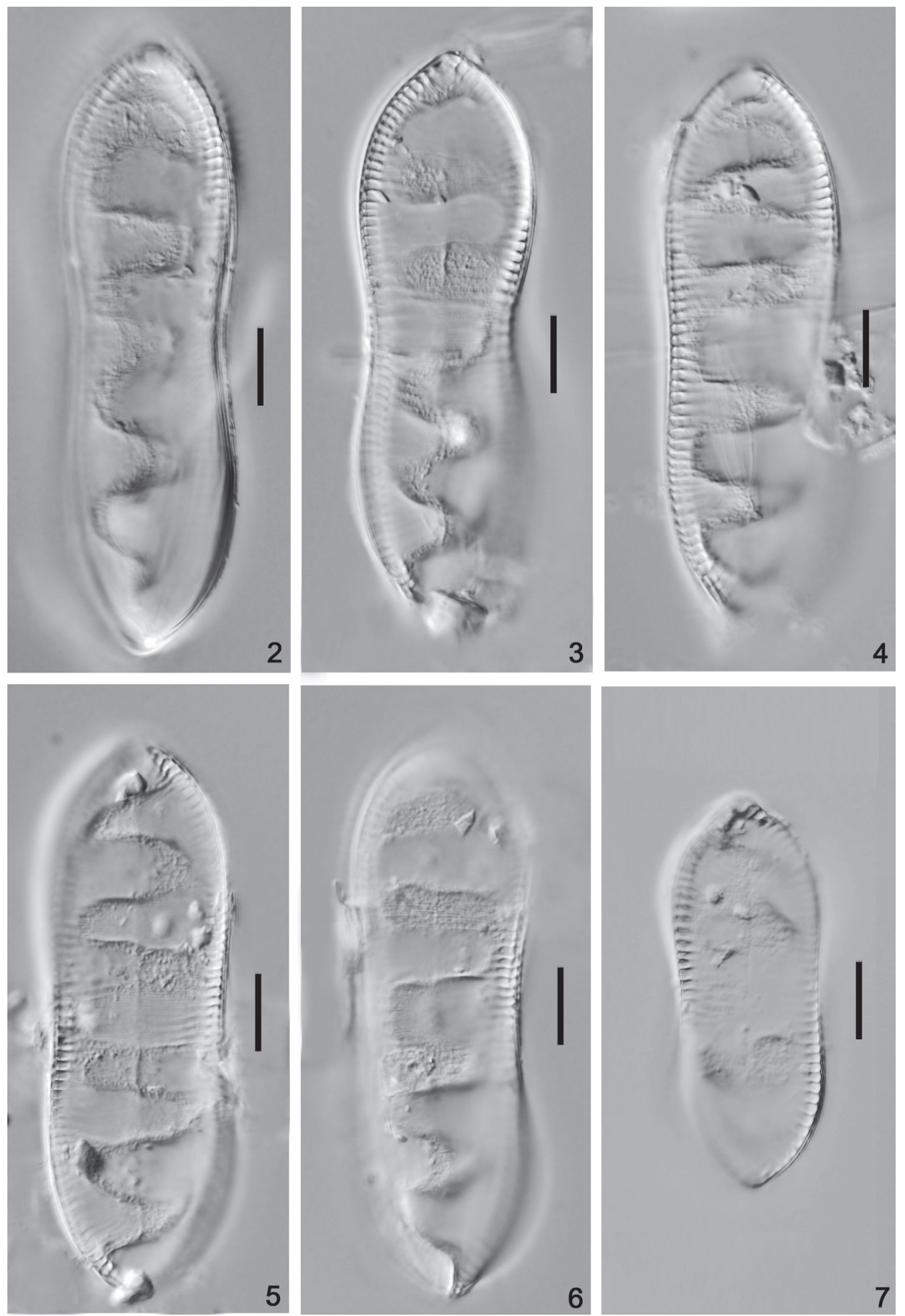

Figs 2-7. Cymatopleura aquastudia LM micrographs of valve views showing size diminution series. Fig. 4 is of the holotype. Scale bars 10 $\mu \mathrm{m}$.

ed margins in the middle and rounded, slightly protracted apices. Valve face with 3-6 transapical undulations. Length $50.5-125.0 \mu \mathrm{m}$, breadth $17.0-25.0 \mu \mathrm{m}$ in the middle (constricted), 18.0-28.0 $\mu \mathrm{m}$ at the widest points. Length-to-breadth ratio 2.9-5.8 at the widest part. Costae 7-9 in $10 \mu \mathrm{m}$, more developed near the margin than on the rest of the valve face, and almost reaching the axial area. Axial area narrow, forming a nearly straight line. Striae fine, difficult to observe in LM.

Scanning electron microscopy (Figs 8-17): External view of valve (Figs 8-13). Valve face with obvious transapical undulations. Narrow costae elevated above the valve face, and evident from valve margin to the 

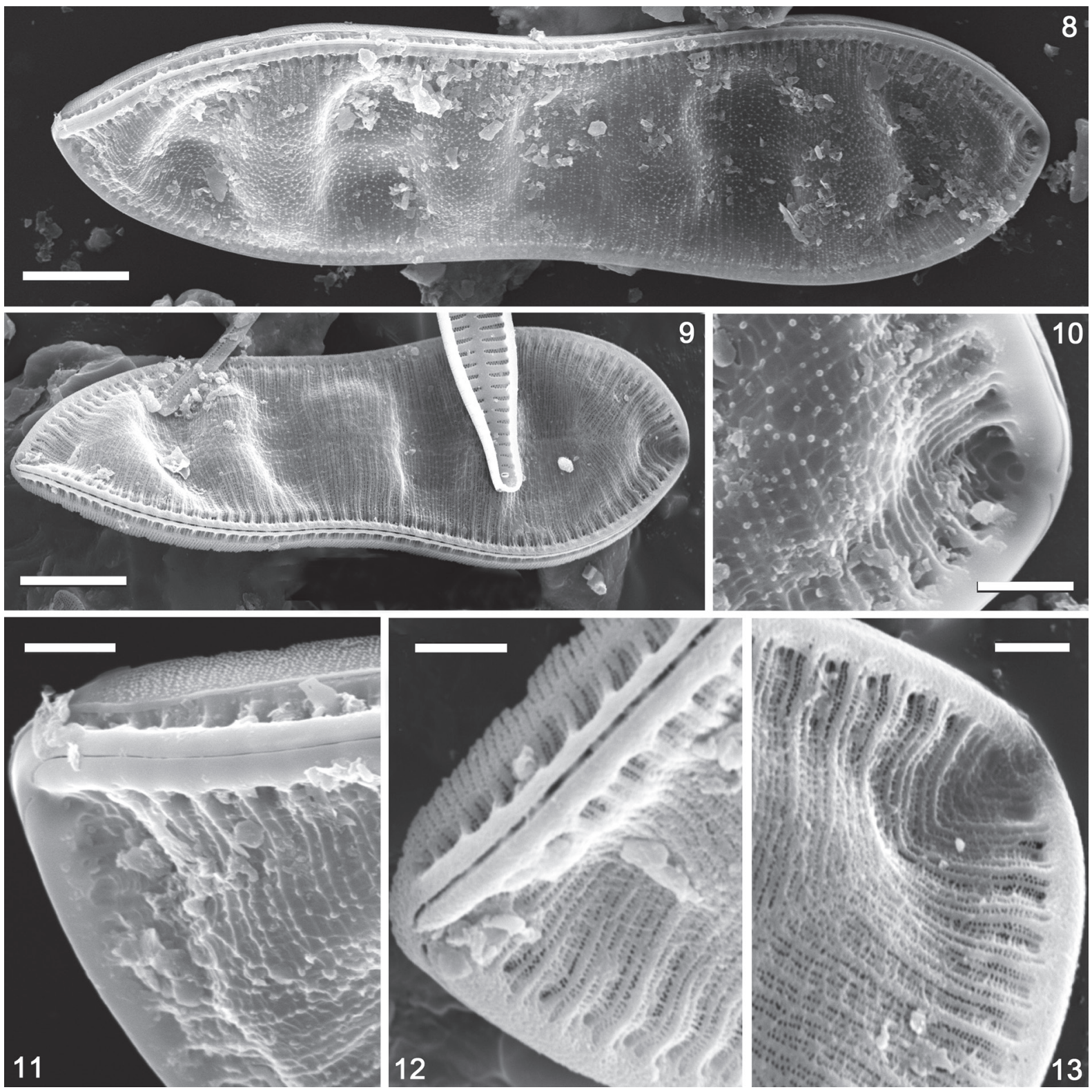

Figs 8-13. Cymatopleura aquastudia SEM, entire external views: (8-9) valve view showing entire valve. Note undulations in the center of the valve, with keel extending around the periphery; (10) wider end of the valve showing valve surface and terminal raphe endings; (11) narrower end of the valve showing valve surface and terminal raphe ending; (12) narrower end showing areolae arrangement, raphe slit and terminal raphe endings; (13) wider end showing striae and thickened ribs. Scale bars $10 \mu \mathrm{m}(8-9) ; 2 \mu \mathrm{m}(10-13)$.

narrow axial area. Transapical costae are parallel in the middle of the valve and converge at the ends. Scattered silica granules are present on the valve face. There is a siliceous layer on the valve surface covering the areolae of the striae, obscuring the striae externally. Striae are doubly-punctate at the margin, becoming uniseriate in the middle of the valve. Areolae 80-95 in 10 $\mu \mathrm{m}$, denser towards the raphe. Raphe positioned on a shallow keel, simple. Raphe with terminal raphe endings near both poles. Raphe fissures are not enlarged, but slightly curved towards the valve face.

Internal view of valve (Figs 14-17). Striae are uniseriate, composed of small, round areolae, possessing rims on the internal surface, 80-95 areolae per $10 \mu \mathrm{m}$. Within the interfibular space, striae are biseriate, and the areolae lack rims. Fibulae are rib-like, $8-9$ per 10 $\mu \mathrm{m}$, evenly spaced to connect valve face and narrow mantle. Raphe is simple, and continuous at both poles, without terminal raphe ends.

Holotype: Slide and material numbered XJ010192, deposited at Shanghai Normal University (SHTU).

Iconotype: Fig. 4.

Type locality: Temporary pond on the roadside, with Chara, sample XJ010192, Chabuchaer, Xinjiang. Water temperature $20^{\circ} \mathrm{C}, \mathrm{pH}$ 8.2. Coll. date 8. 8. 2001.

Etymology: The specific epithet in Latin, "aquastudia" means "intermittent water" referring that the new species is found in small ponds and ditches. 

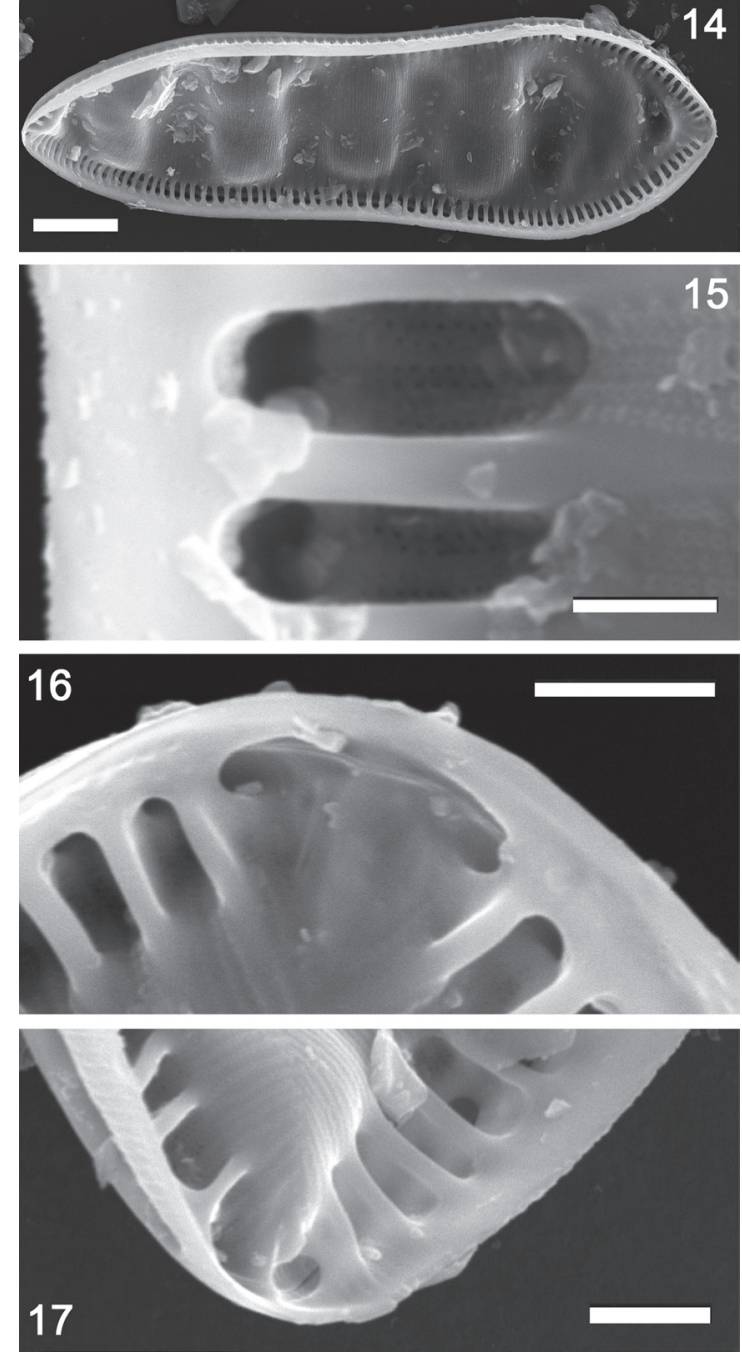

Figs 14-17. Cymatopleura aquastudia SEM, entire internal views: (14) valve view showing entire valve. Undulations are prominent; (15) valve margin showing fibular structure and details of areolae in the valve surface and between fibulae; (16) wider end of the valve showing valve surface and continuous raphe fissure; (17) more narrow end of the valve showing fibulae and raphe end. Scale bars 10 $\mu \mathrm{m}(14) ; 1 \mu \mathrm{m}(15) ; 2 \mu \mathrm{m}(16,17)$.

Ecology and Distribution: Cymatopleura aquastudia was widely distributed in the Xinjiang Region, and observed in samples collected in Akesu (XJ010112, XJ010117), Bohu(XJ010128), Chabuchaer(XJ010183, XJ010192) and Yecheng (XJ071055). These sites are distributed in \& south of Tianshan Mountains Region, near the Kunlun Mountains Region; specific locations are given in figure 1. The type population of $C$. aquastudia was observed in an alkaline, temporary pond on the roadside. This new species was also found in small, clean ditch, with aquatic plants, and alkaline pH (see Table 1).

Remarks: Cymatopleura aquastudia resembles $C$. solea (BRÉBISSON) W. SMITH (1851), by its panduriform valve outline. Cymatopleura aquastudia differs from C. solea by being twisted about the apical axis, and be- ing slightly asymmetrical to the transapical axis. This new species is morphologically similar to $C$. spiralis BeHning (in Rauschenbach \& BeHning 1912), a species described from a plankton sample taken in the Winter from the Volga River in Russia. While both taxa have panduriform outlines, they differ in that the new species described here is heteropolar, with slightly constricted middle margins. Cymatopleura spiralis is isopolar, similar to C. solea, and with obviously constricted margins in the middle (RAUSCHENBACH \& BEHNING 1912, figure II: 1-2). The difference between this new species and other Cymatopleura possessing valves with torsion is summarized in Table 2 .

Cymatopleura xinjiangiana You et KocıoLeK sp. nov. (Figs 18-33)

\section{Description}

Light microscopy (Figs 18-23): Frustules with a more or less slight torsion about the apical axis. Valves broadly wedge-shaped and asymmetrical to the transapical axis, without a median constriction, with apices rounded and protracted at the wider end, narrowly rounded and more cuneate at the narrower end. Valve face with 3-5 transapical undulations. Valve length 45.0-75.0 $\mu \mathrm{m}$, breadth 18.0-21.0 $\mu \mathrm{m}$. Length-tobreadth ratio $2.4-3.5$. Costae $7-9$ in $10 \mu \mathrm{m}$, more developed near the margin than on the rest of the valve face, and almost reaching the axial area. Axial area narrow, forming a nearly straight line. Striae fine, difficult to observe in LM.

Scanning electron microscopy (Figs 24-33): External view of valve (Figs 24-28). Valve face with obvious transapical undulations. Narrow costae raised just above the valve face, and elevated from the valve margin to the axial area. Transapical costae oriented parallel in the most part of the middle valve, convergent at the ends. Irregular siliceous elements between costae give the valve surface a reticulate appearance, with scattered siliceous granules present on the valve face. There is a silica layer on the valve surface covering the areolae, obscuring the striae externally. Raphe located in a short keel and simple, with terminal raphe ends evident near the two poles. Raphe fissures not enlarged and slightly curved onto the valve surface.

Internal view of valve (Figs 29-33). Valve face with obvious transapical undulations. Striae are uniseriate, composed of small, round areolae, each areola is rimmed by a narrow outline of silica. Areolae 75-85 per $10 \mu \mathrm{m}$. Striae are biseriate, and areolae are without rims within the interfibular space. Fibulae are rib-like, 9-11 per $10 \mu \mathrm{m}$, evenly spaced connecting valve face and narrow mantle. Raphe is simple, continuous to the apices, without terminal ends.

Holotype: Slide and material numbered XJ010183, deposited at Shanghai Normal University (SHTU).

Iconotype: Fig. 20. 
Table 2. Comparison of valve features between two new spiral Cymatopleura species and other similar Cymatopleura species.

\begin{tabular}{|c|c|c|c|c|c|c|}
\hline Species & Outline & Spiral status & $\begin{array}{l}\text { Length } \\
(\mu \mathrm{m})\end{array}$ & $\begin{array}{l}\text { Breadth } \\
(\mu \mathrm{m})\end{array}$ & $\begin{array}{l}\text { Costae } \\
/ 10 \mu \mathrm{m}\end{array}$ & Sources \\
\hline C. aquastudia & $\begin{array}{l}\text { Panduriform and heteropo- } \\
\text { lar, with slightly constricted } \\
\text { middle margins and round- } \\
\text { ed, slightly protracted ends }\end{array}$ & $\begin{array}{l}\text { Spiral along the } \\
\text { apical axis, curved } \\
\text { ridges existed at } \\
\text { both ends }\end{array}$ & $50.5-94$ & $17-21$ & $7-9$ & This study \\
\hline C. xinjiangiana & $\begin{array}{l}\text { Wedge-shaped and hetero- } \\
\text { polar, without constricted } \\
\text { margins and rounded, pro- } \\
\text { tracted ends at the wider } \\
\text { ends }\end{array}$ & $\begin{array}{l}\text { Spiral along the } \\
\text { apical axis, curved } \\
\text { ridges existed at } \\
\text { both ends }\end{array}$ & $45.5-70$ & $18.5-20.5$ & $7-9$ & This study \\
\hline C. solea & $\begin{array}{l}\text { Panduriform, isopolar,with } \\
\text { constricted middle margins } \\
\text { and rounded, protracted ends }\end{array}$ & Without spiral & $51-254$ & $\begin{array}{l}1 / 10 \text { of } \\
\text { length }\end{array}$ & - & Sмітн 1851 \\
\hline C. cochlea & $\begin{array}{l}\text { Wedge-shaped and hetero- } \\
\text { polar, without constricted } \\
\text { margins and rounded at the } \\
\text { wider ends }\end{array}$ & $\begin{array}{l}\text { Spiral, curved ridge } \\
\text { only existed at nar- } \\
\text { row ends }\end{array}$ & $120-150$ & $55-65$ & $5-8$ & BRUN 1891 \\
\hline $\begin{array}{l}\text { C. elliptica } \mathrm{f} . \\
\text { spiralis }\end{array}$ & $\begin{array}{l}\text { Wedge-shaped and hetero- } \\
\text { polar, without constricted } \\
\text { margins and rounded at the } \\
\text { wider ends }\end{array}$ & $\begin{array}{l}\text { Spiral, curved ridge } \\
\text { only existed at nar- } \\
\text { row ends }\end{array}$ & $70-140$ & - & 3 & BOYER 1916 \\
\hline C. spiralis & $\begin{array}{l}\text { Panduriform, isopolar, with } \\
\text { obviously constricted middle } \\
\text { margins and rounded, pro- } \\
\text { tracted ends }\end{array}$ & $\begin{array}{l}\text { Spiral along the api- } \\
\text { cal axis }\end{array}$ & 129.43 & $19.3-38.6$ & - & $\begin{array}{c}\text { RAUSCHEN- } \\
\text { BACH, \& } \\
\text { BEHNING } \\
1912\end{array}$ \\
\hline
\end{tabular}

Table 3. Morphometry statistic of Cymatopleura aquastudia and Cymatopleura xinjiangania.

\begin{tabular}{lcc}
\hline & C. aquastudia & C. xinjiangania \\
\hline Number of cells measured & $\mathbf{3 0}$ & $\mathbf{3 0}$ \\
\hline Length & & \\
\hline Range & $50.5-125.0$ & $45.0-75.0$ \\
Mean & 85.2 & 61.5 \\
Standard Deviation & 17.4 & 7.9 \\
\hline Breadth (widest) & & $18.0-21.0$ \\
\hline Range & $18.0-28.0$ & 20.2 \\
Mean & 24.1 & 1.0 \\
Standard Deviation & 2.5 & \\
\hline Length / Breadth (widest) & & $2.4-3.5$ \\
\hline Range & $2.9-5.8$ & 3.0 \\
Mean & 4.1 & 0.3 \\
Standard Deviation & 0.6 & \\
\hline
\end{tabular}



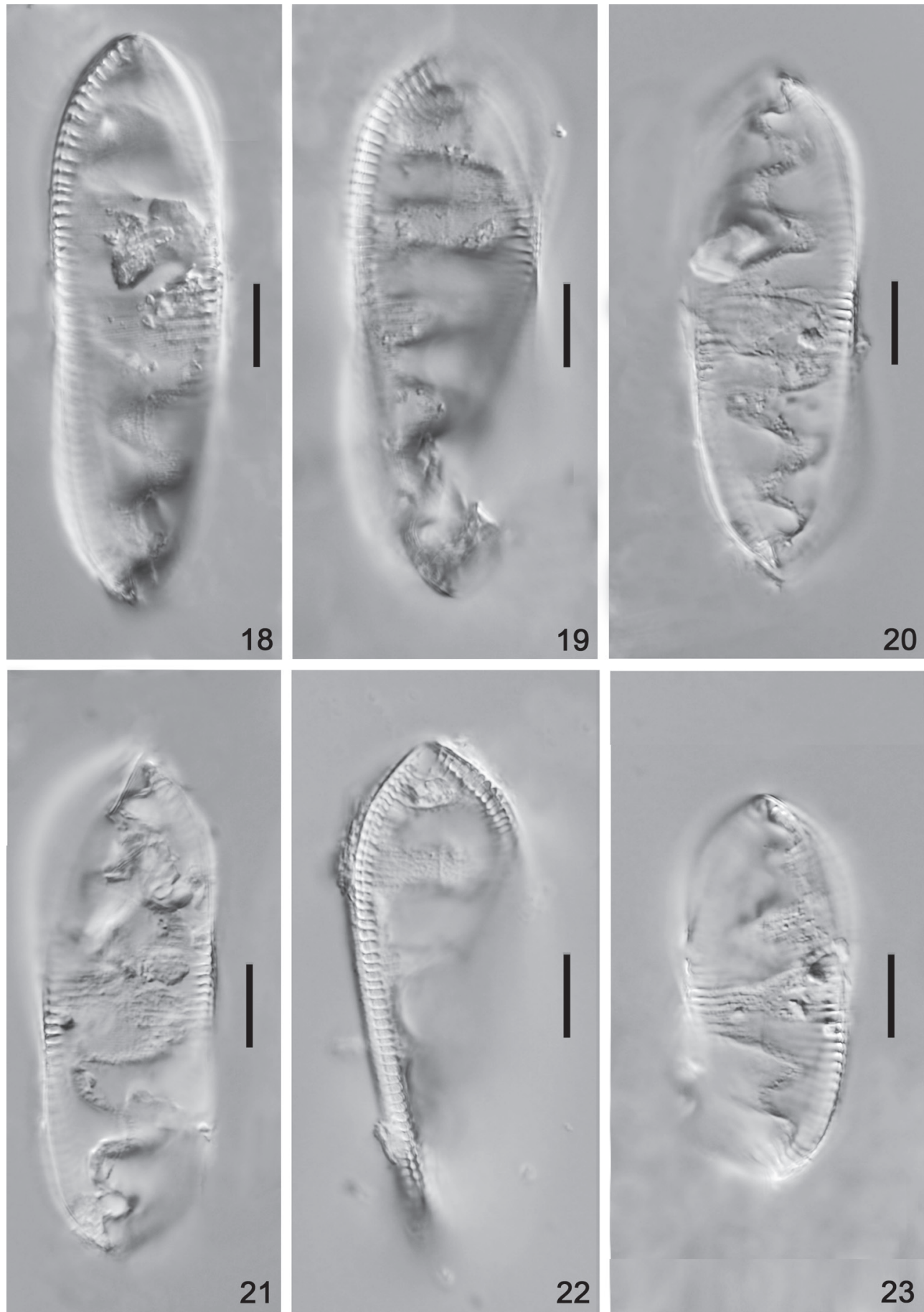

Figs 18-23. Cymatopleura xinjiangiana LM micrographs of valve views showing size diminution series. Fig. 20 is of the holotype. Scale bars $10 \mu \mathrm{m}$.

Type locality: Temporary pond on the roadside, with Chara, sample XJ010183, Chabuchaer, Xinjiang. Temperature $20^{\circ} \mathrm{C}, \mathrm{pH}$ 8.2. Coll. date 8. 8. 2001 .

Etymology: The species is named for the Xinjiang Region, where it was found.

Ecology and Distribution: Cymatopleura xinjiangiana was observed in samples collected at Bachu (XJ010105), Akesu (XJ010117) and Chabuchaer (XJ010183). These sites are mainly distributed around the Tianshan Mountains Region, specific locations are seen in figure 1 . The type population of $C$. xinjiangia$n a$ was observed in an alkaline temporary pond on the roadside, with Chara. This new species was also found in similar ecological conditions in the region but populations were very small (see Table 1).

Remarks: This new species is morphologically similar to Cymatopleura cochlea BRUN (1891) and C. elliptica f. spiralis BOyer (1916), in that all three taxa are het- 

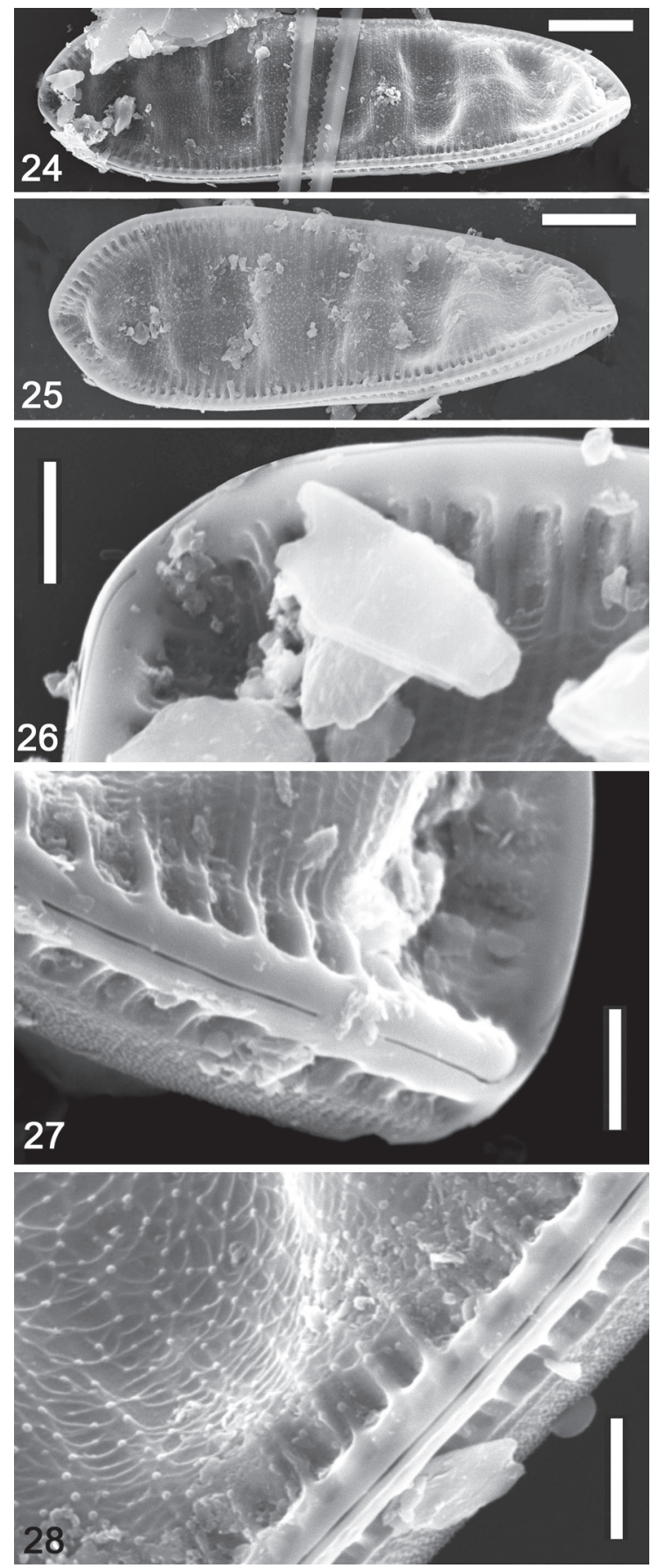

Figs 24-28. Cymatopleura xinjiangiana SEM, entire external views: (24-25) valve view showing entire valve. Undulations in the center of the valve are evident, degree of torsion is slight; (26) wider end of the valve showing valve surface and terminal raphe endings, close together but separate; (27) narrower end of the valve showing valve surface, keel and terminal raphe ending; (28) margin of valve showing fine costae, raphe fissure and narrow mantle. Scale bars $10 \mu \mathrm{m}$ (24-25); $2 \mu \mathrm{m}(26-28)$.

eropolar and have twisted frustules. There are, however, obvious differences in outline and valve characters between the three taxa. The valves of the new species found in Xinjiang have rounded apices and are protracted at the wider ends. Frustules are twisted along the apical axis, and curved ridges can exist at
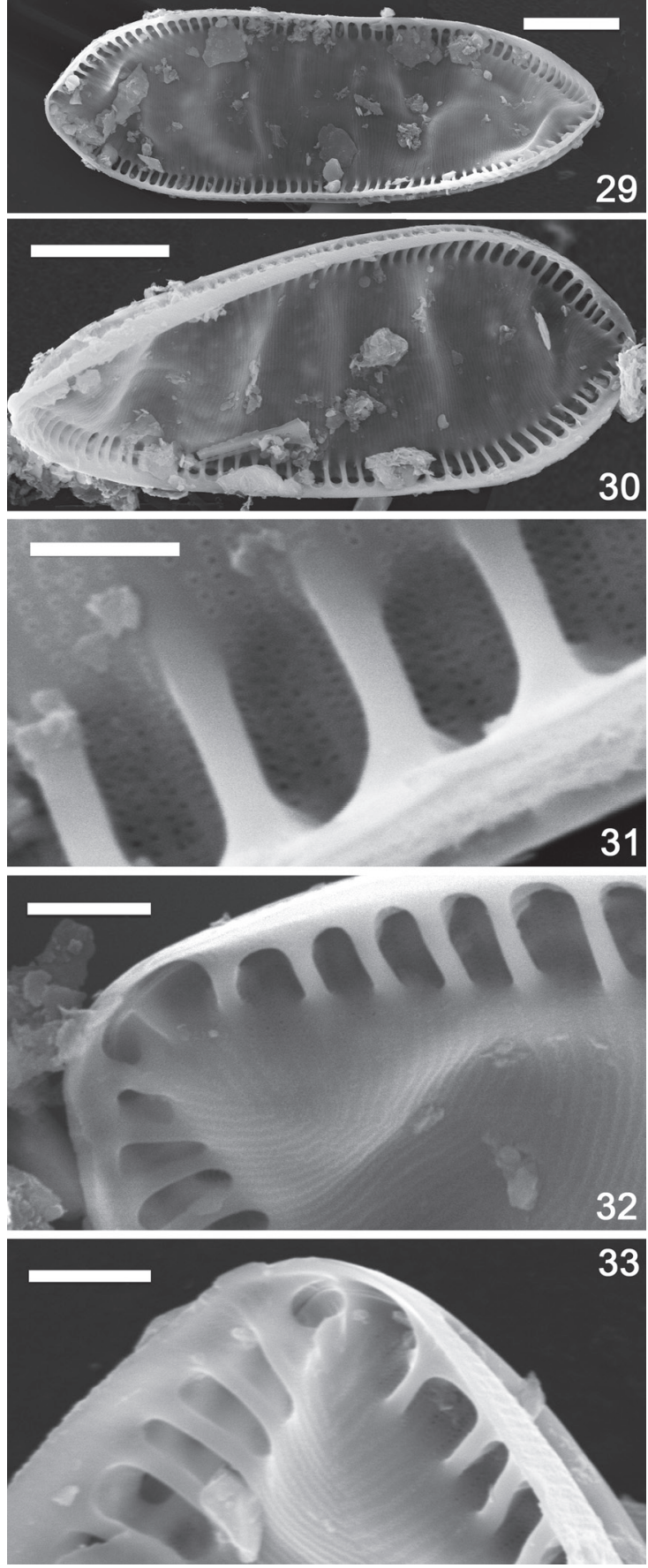

Figs 29-33. Cymatopleura xinjiangiana SEM, entire internal views: (29-30) valve views of entire cell. Undulations and fibulae are evident; (31) fibulae structure and details of areolae in the valve surface and between fibulae; (32) wider end of the valve showing valve surface, fibulae and continuous raphe fissure; (33) narrower end of the valve showing valve surface, fibulae and continuous raphe fissure. Scale bars $10 \mu \mathrm{m}(29-30) ; 1 \mu \mathrm{m}(31) ; 2 \mu \mathrm{m}(32-33)$.

both ends. In C. elliptica f. spiralis and C. cochlea, there are no protracted wider ends and the apices are rounded, the frustules are twisted slightly, and curved ridges only occur at the narrower ends. Moreover, $C$. cochlea has larger frustules, with length $120-150 \mu \mathrm{m}$ and breadth 55-65 $\mu \mathrm{m}$ (BRUN 1891); it is larger than 
Xinjiang species (length 45-75 $\mu \mathrm{m}$, breadth 18-21 $\mu \mathrm{m})$. According to the description of Boyer (1916), $C$. elliptica f. spiralis is the same size as nominate species (C. elliptica (BRÉBISSON et KüTZING) W. SMITH; length $70-140 \mu \mathrm{m})$, thus it also larger than the new species from Xinjiang Region. Detailed differences about outline, length, width and costae of these species are compiled in Table 2 .

\section{Discussion}

The only Cymatopleura species previously described from China is $C$. sinensis Skvortzow, known only from ponds in Tianjin ("Tientsin" SkvorTzow 1927). The species described by Skvortzow is long and slender, 52.7-74.5 $\mu \mathrm{m}$ long, $5.1 \mu \mathrm{m}$ wide, with broadly rounded apices and has 5-6 undulations on the valve face (Skvortzow 1927; fig. 27). You (2009) and You \& WANG (2011) reported Cymatopleura cochlea from the Xinjiang Region, however recently we re-examined these samples with LM and SEM and the Cymatopleura taxa present with twisted valves can be separated into two distinct morphologies, one with a median constriction similar to $C$. solea and one asymmetrical to the transapical axis. These two morphologies represent the new taxa described here. Since neither of these morphologies are similar to $C$. cochlea, we cannot verify the occurrence of $C$. cochlea in Xinjiang as reported by You (2009) and You \& WANG (2011).

Previously described Cymatopleura taxa with twisted valves, including C. cochlea (BRUN 1891), C. spiralis (RAuscheNBACH \& BEHNING 1912) and C. elliptica f. spiralis (BOYER 1916) were described before the early part of last century, and the frustules are large in size and easy to distinguish. They were only originally recorded in several locations, and based on very few specimens. In the original description of C. cochlea, the species was reported to be found in Cabenda (in present day Angola, Africa), in the port of New York City and Port-au-Prince, Haiti (BRUN 1891). It has, more recently been reported from the Laurentian Great Lakes (Stoermer et al. 1978, 1999; Kociolek 2005), Iowa (OHL 1965; Begres 1971) and Taiwan (SHAO 2003-2014). Cymatopleura spiralis has only been reported from the type locality, the Volga River near Saratov, Russia (Rauschenbach \& BeHning 1912). Cymatopleura elliptica f. spiralis was originally reported from the Delaware River (Port Penn), and subsequently reported from the Laurentian Great Lakes (STOERMER 1978, 1999) and lakes in Nebraska (EBERLe 2008). So far, the two, new species described herein are known only from Xinjiang Region.

\section{ACKnowledgements}

This research was supported by Project of Shanghai Normal University (DYL201701) and the National Natural Science
Foundation of China (No. 30670154 \& 31100151). We would like to thank Hailing Li and Wanting PANG for their helps with the collection of materials in the field and laboratory work.

\section{REFERENCES}

BAHLs, L. (2013): New diatoms (Bacillariophyta) from western North America. - Phytotaxa 82: 7-28.

Begres, F.M. (1971): The diatoms of Clear Lake and Ventura Marsh, Iowa [Ph.D. Thesis]. - 199pp., Iowa State University, Ames, Iowa.

Boyer, C.S. (1916): The Diatomaceæ of Philadelphia and vicinity. -143 pp., Press of J. B. Lippincott Company, Philadelphia.

BRUN, J. (1891): Diatomées espèces nouvelles marines, fossiles ou pélagiques. - Mémoires de la Société de Physique et d'Histoire Naturelle de Genève 31(part 2, no.1): 1-47, pl. 11-22.

Chang, T-P \& Steinberg, C. (1988): Epiphytische Diatomeen auf Cymatopleura und Nitzschia. - Diatom Research 3: 203-216.

Cocquyt, C. \& JAHN, R. (2005): Ten rare Surirella species from East Africa described by Otto Müller: typifications, recombinations, new names, annotations and distributions. - Willdenowia 35: 359-371.

Cocquyt, C. \& JAhN, R. (2007): Surirella nyassae O. Müller, S. malombae O. Müller and S. chepurnovii Cocquyt \& R. Jahn sp. nov. (Bacillariophyta) - typification and variability of three closely related East African diatoms. - Nova Hedwigia 84: 529-548.

CocquYt, C. \& JAHN, R. (2014): A re-investigation of O. Müller's Cymatopleura taxa (Bacillariophyta) from East Africa. - Plant Ecology and Evolution 147: $412-425$

EBERLE, M.E. (2008): Recent diatoms reported from the central United States: register of taxa and synonyms. Hays, Kansas: Department of Biological Sciences, Fort Hays State University. Latest electronic version: 5 December 2008.

Fourtanier, E. \& Kociolek, J.P. (2011): Catalogue of Diatom Names. - California Academy of Sciences, Online Version updated 19 Sep 2011. Available online at http://research.calacademy.org/research/diatoms/ names/index.asp

Karsten, G. (1900): Die Auxosporenbildung der Gattungen Cocconeis, Surirella und Cymatopleura. - Flora 87: 253-283.

Karsten, G. (1928): Bacillariophyta. - In: Engler, A. \& Prantl, K. (eds): Die natürlichen Pflanzenfamilien, 2nd Ed., 2: 105-303.

Kociolek, J.P.; You, Q.-M.; WAng Q.-X. \& Liu Q. (2015): A Consideration of some interesting freshwater gomphonemoid diatoms from North America and China, and the description of Gomphosinica, gen. nov. Nova Hedwigia, Beiheft 144: 175-198.

Kociolek, J.P. (2005): A checklist and preliminary bibliography of the Recent, freshwater diatoms of inland environments of the continental United States. - Proceedings of the California Academy of Sciences. Fourth Series 56: 395-525.

Levkov, Z.; Krstic, S.; Metzeltin, D. and Nakov, T. (2007): Diatoms of lakes Prespa and Ohrid, about 500 taxa from ancient lake system. - In: LANGe-Bertalot, H. 
(ed.): Iconographia Diatomologica. Annotated Diatom Micrographs. Vol. 16. Biogeography, Ecology, Taxonomy. - 613 pp., A.R.G. Gantner Verlag K.G.

ManN, D.G. (1987): Sexual Reproduction in Cymatopleura. - Diatom Research 2: 97-112.

OHL, L.E. (1865): Diatoms of Iowa farm ponds [Ph.D. Thesis]. - 199 pp., Iowa State University of Science and Technology.Ames, Iowa.

PARR J.F.; TAFFs K.H. \& LANE C.M. (2004): A microwave digestion technique for the extraction of fossil diatoms from coastal lake and swamp sediments. - Journal of Paleolimnology 31: 383-390.

Pfitzer, E. (1871): Untersuchungen über Bau und Entwickelung der Bacillariaceen (Diatomaceen). - In: HANSTEIN (ed.): Botanische Abhandlungen 2: 1-189.

RauschenBach, W. \& Behning, A. (1912): Bemerkungenuber das Winterplankton der Wolga dei Saratow. - Arbeit. d. biol. Wolga-Station. 4: 1-56.

Ross, R. (1983): Endemism and cosmopolitanism in the diatom flora of the East African Great lakes. - In: Sims, R.W.; Price, J.H. \& Whalley, P.E.S. (eds): Evolution, time and space. Systematics Association Special, Vol. 23. - pp. 157-177, University Press, London.

Round, F.E.; Crawford, R.M. \& Mann, D.G. (1990): The Diatoms. Biology and Morphology of the Genera. 747 pp., Cambridge University Press, Cambridge.

Ruck, E.C. \& Kociolek, J.P. (2004): A preliminary phylogeny of the family Surirellaceae. - Bibliotheca Diatomologica 50: 1-236.

Ruck, E.C. \& THERIOT, E.C. (2011): Origin and Evolution of the Canal Raphe System in Diatoms. - Protist 162: 723-37.

Shao, K.T. (2003-2014): TaiBNET. Catalogue of Life in Taiwan. - http://taibnet.sinica.edu.tw. Taiwan.

Skvortzow, B.W. (1927): Diatoms from Tientsin, North China. - Journal of Botany 65: 102-109.

Sмith, W. (1851): Notes on the Diatomaceae, with descriptions of British Species included in the genera Campylodiscus, Surirella and Cymatopleura. - Annals and Magazine of Natural History, 2nd series, 7: 1-14.

Spaulding, S. \& Edlund, M. (2008): Cymatopleura. In Diatoms of the United States. - Retrieved September 19, 2016, from http://westerndiatoms.colorado.edu/taxa/ genus/Cymatopleura

Stoermer, E.F. \& Kreis, R.G.Jr. (1978): Preliminary checklist of diatoms (Bacillariophyta) from the Laurentian Great Lakes. - Journal of Great Lakes Research 4: 149-169.

Stoermer, E.F.; Kreis, R.G.Jr. \& Andresen, N.A. (1999): Checklist of Diatoms from the Laurentian Great Lakes. II. - Journal of Great Lakes Research 25: 515-566.

ThaLeR, F. (1972): Beitrag zur Entwicklungsgeschichte und zum Zellbau einiger Diatomeen. - Österreichische Botanische Zeitschirift 120: 313-347.

You, Q-M. (2009): Studies on Aulonoraphidinales (BACILlariophyta) OF FRESHWATER IN ChINA [Unpublished Ph.D. Thesis]. - 363 pp., East China Normal University, China.a

You, Q.-M.; Kociolek, J.P. \& Wang, Q.-X. (2013): New Gomphoneis Cleve (Bacillariophyceae: Gomphonemataceae) species from Xinjiang Province, China. Phytotaxa 103: 1-24.
You, Q.-M.; Kociolek, J.P. \& WAnG, Q.-X. (2015a): The diatom genus Hantzschia (Bacillariophyta) in Xinjiang province, China. - Phytotaxa 197: 1-14.

You, Q.-M.; LiU, Y.; WANG, Y.-F. \& WANG, Q.-X. (2008): Synedra ulna var. repanda, a new variety of Synedra (Bacillariophyta) from Xinjiang, China. - Chinese Journal of Oceanology and Limnology 26: 419-420.

You, Q.-M.; LiU, Y.; Wang, Y.-F. \& WANG, Q.-X. (2009): Taxonomy and distribution of diatoms in the genera Epithemia and Rhopalodia from the Xinjiang, China. - Nova Hedwigia 89: 397-430.

You, Q.-M. \& WANG, Q.-X. (2011): Four Newly Recorded Species of Surirellaceae (Bacillariophyta) in China.Plant Science Journal 29: 260-264.

You, Q.-M.; WANG, Q.-X. \& KocioleK, J.P. (2015b): New Gomphonema Ehrenberg (Bacillariophyceae; Gomphonemataceae) species from Xinjiang Province, China. - Diatom Research 30: 1-12.

(C) Czech Phycological Society (2017)

Received December 14, 2016

Accepted April 12, 2017 